\title{
A single center series highlights on incidence and management of gastric neuroendocrine tumours with literature review
}

\author{
Fahmy WF ${ }^{1, *}$, Khokhar $\mathrm{HA}^{1}$, Meshkat $\mathrm{B}^{1}$, Babikir $\mathrm{S}^{1}$, Azeem $\mathrm{B}^{1}$ and Tobbia $\mathrm{IN}^{1}$ \\ ${ }^{1}$ Connolly Hospital Blanchardstown, Dublin 14, Ireland
}

\begin{abstract}
Neuroendocrine tumours of the digestive system (GEP-NET) are relatively rare. Nevertheless, their diagnoses is rising as seen from studies in the US and elsewhere. Gastric neuroendocrine tumours (Gastric NETs) vary through a wide clinical spectrum, from asymptomatic cases to functioning tumours. Gastrointestinal specialists need to be aware and pursue these lesions as they are indolent with a malignant variant and a potential for metastasis. A computerised search through our pathology laboratory data base, using codes for gastric, carcinoid and neuroendocrine tumour/ hyperplasia, was used to identify cases from January 2008 to September 2014. Medical charts were retrieved, examined. Eleven cases were identified and re-examined by one consultant pathologist. There were 5 females - mean age of 50 years (39-59) and 6 males - mean age of 57 years (41-73). Mean follow up period was 4.5 years (1-9). Gastric NETs fall into Type I, II and III (WHO Classification). Our series showed eight cases of Type I managed by biopsy/ endoscopic mucosal resection (EMR). No Type II cases were identified and one case of Type III had a subtotal gastrectomy and lymphadenectomy. Two neuroendocrine hyperplasia cases were managed by biopsy only. Cases were followed up (except one who refused) with regular upper endoscopy and imaging as indicated. A literature review of managing Gastric NETs was discussed. We aim to alert gastrointestinal specialists by presenting a retrospective study of Gastric NETs from a single teaching institution.
\end{abstract}

Keywords: gastric; neuroendocrine tumour; hyperplasia; incidence; management of gastric

\section{Introduction}

In the last decade, gastrointestinal physicians and surgeons have noticed an increased incidence of neuroendocrine growths occurring in the stomach while performing routine upper gastrointestinal (UGI) endoscopies. All of these lesions were histopathologically proven, a fact which sometimes took them by surprise.

Neuroendocrine tumours (NETs) are epithelial neoplasms principally with neuroendocrine differentiation. They arise commonly in the gastrointestinal tract (67\%) and broncho pulmonary system (25\%) although other sites such as kidneys and ovaries lesions is recorded They have the potential of secreting humoral factors that lead to carcinoid syndrome [1].

Gastric neuroendocrine tumours (Gastric-NETs), the focus of our series, accounts for $0.6-2 \%$ of all gastric polyps identified [2]. In the surveillance, Epidemiology and End Results Program (SEER) data, Gastric NETs incidence has risen reporting a 7\% of GEP-NET [3]. It has a yearly ageadjusted incidence of approximately 0.2 per population of 100,000 . This is probably under reported as presented in other studies to be up to $23 \%$ of GEP NETs probably due to expanding upper $\mathrm{Gl}$ endoscopy indications [4].

In support of similar observations worldwide, we present a retrospective study of eleven Gastric NETs encountered during our practice, in a relatively small teaching hospital
(242 beds), over the period from January 2008 to September 2014. The majority of these cases were incidentally seen and diagnosed. The aim is to highlight the incidence of Gastric NETs and its management.

\section{Materials and methods}

We conducted a computer search through our pathology laboratory data base. Codes for gastric, carcinoid and neuroendocrine tumour/ hyperplasia/ carcinoma were used to identify the cases for the period, January 2008 to September 2014. Medical charts were retrieved, examined and a summary table was presented.

\section{Results and discussions}

A total number of 11 cases were identified through the study period. All identified cases were reviewed by one of

*Corresponding author: Fahmy WF, Connolly Hospital Blanchardstown, Dublin 14, Ireland. Email: waleedfahmy33@yahoo.com

Received 3 March 2015 Revised 3 May 2015 Accepted 16 May 2015 Published 22 May 2015

Citation: Fahmy WF, Khokhar HA, Meshkat B, Babikir S, Azeem B, Tobbia IN. A single center series highlights on incidence and management of gastric neuroendocrine tumours with literature review. J Cancer Res Ther. 2015; 3(5):66-71. DOI:10.14312/2052-4994.2015-9

Copyright: @ 2015 Fahmy WF, et al. Published by NobleResearch Publishers. This is an open-access article distributed under the terms of the Creative Commons Attribution License, which permits unrestricted use, distribution and reproduction in any medium, provided the original author and source are credited. 
our consultant pathologists. There were 5 females with a mean age of 50 years [39-59] and 6 males with a mean age of 57 years [41-73]. Mean follow up period was 4.5 years [1-9]. Table 1 summarises these results.

Table 1: Summary of the results

\begin{tabular}{|c|c|c|c|c|c|c|c|c|c|}
\hline Patient & Age & Gender & Symptoms & Lesion & Investigations & Biopsy & Treatment & Follow up & $\begin{array}{l}\text { Out- } \\
\text { come }\end{array}$ \\
\hline 1-C.M & 59 & $\mathrm{~F}$ & $\begin{array}{l}\text { Abdominal } \\
\text { pain and } \\
\text { diarrhea }\end{array}$ & $\begin{array}{l}\text { Body nodule } \\
>1 \mathrm{~cm} \\
\text { (Greater curve) }\end{array}$ & $\begin{array}{l}\text { OGD+Bxy 2010, CT AP 2010: } \\
\text { Greater curve polyp > 1cm No } \\
\text { nodes, EUS 2010: } 1.1 \mathrm{~cm} \text { nodule, } \\
7 \text { mm gastrohepatic nodes, Oct. } \\
\text { Scan } 2010 \text { negative }\end{array}$ & $\begin{array}{l}\text { WDNET, G1, } \\
\text { ki } 67:<2 \% \\
\text { T1N0M0 }\end{array}$ & $\begin{array}{l}\text { EMR } 2010 \\
\text { (incomplete } \\
\text { excision), Sleeve } \\
\text { gastrectomy } \\
2011 .\end{array}$ & $\begin{array}{l}\text { MDT : } \\
\text { Annual } \\
\text { OGD }\end{array}$ & Well \\
\hline $\begin{array}{l}\text { 3-M. } \\
\text { McG }\end{array}$ & 50 & $\mathrm{~F}$ & $\begin{array}{l}\text { Epigastric } \\
\text { pain/ } \\
\text { Pernicious } \\
\text { anaemia }\end{array}$ & $\begin{array}{l}\text { Lesser curve } \\
\text { polyp } \\
<1 \mathrm{~cm}\end{array}$ & $\begin{array}{l}\text { OGD 2008, CT AP 2008: Normal, } \\
\text { PET CT 2008: No increased } \\
\text { uptack., Oct scan } 2009 \text { Normal, } \\
\text { EUS 2010: ? infiltrative lesion } \\
\text { lesser curve, Oct. scan 2010: Non } \\
\text { specific liver lesion, CT TAP 2010; } \\
\text { Normal. Repeat EUS 2010: 4mm } \\
\text { lesion excision biopsy. }\end{array}$ & $\begin{array}{l}\text { WDNET, G1, } \\
\text { ki } 67:<2 \% \text {, } \\
\text { T1NOM0. } \\
\text { CAG }\end{array}$ & Excision Bxy. & $\begin{array}{l}\text { MDT: } \\
\text { Annual } \\
\text { OGD +/- } \\
\text { EMR }\end{array}$ & Well \\
\hline 4- A.D & 39 & $\mathrm{~F}$ & $\begin{array}{l}\text { Pernicious } \\
\text { anaemia }\end{array}$ & $\begin{array}{l}\text { X2 fundic } \\
\text { polyps } \\
<0.5 \mathrm{~cm}\end{array}$ & $\begin{array}{l}\text { OGD 2011,CT AP Normal, } \\
\text { positive thyroid antibodies }\end{array}$ & $\begin{array}{l}\text { Multi focal } \\
\text { WDNET, G2, } \\
\text { ki 67: 7-10\%, } \\
\text { T1N0M0, } \\
\text { CAG }\end{array}$ & Excision Bxy. & $\begin{array}{l}\text { Annual } \\
\text { OGD }\end{array}$ & Well \\
\hline 5- D.K & 54 & M & $\begin{array}{l}\text { Dyspepsia/ } \\
\text { Pernicious } \\
\text { anaemia }\end{array}$ & $\begin{array}{l}\text { X3 fundic/body } \\
\text { cherry spots. }\end{array}$ & $\begin{array}{l}\text { OGD 2010, CT TAP 2011: small } \\
\text { vascular nodules 3-4 mm (greater } \\
\text { curve), no nodes or mets, Oct } \\
\text { scan: } 2011 \text { Normal, urine 5HIAA: } \\
29.2\end{array}$ & $\begin{array}{l}\text { Diffuse } \\
\text { WDNET, G1, } \\
\text { ki } 67:<1 \% . . \\
\text { T1N0M0 }\end{array}$ & Excision Bxy. & $\begin{array}{l}\text { Annual } \\
\text { OGD }\end{array}$ & Well \\
\hline 6- F.B & 53 & M & Dyspepsia & $\begin{array}{l}\text { Body/antral } \\
\text { lesion } \\
2 \mathrm{~cm}\end{array}$ & $\begin{array}{l}\text { OGD(2010).CT TAP (2010): } 3 \\
\text { cm polypoidal mass in body of } \\
\text { stomach,no nodes or mets }\end{array}$ & $\begin{array}{l}\text { NEC, G3, } \\
\text { ki } 67: 40 \% \text {, } \\
\text { T2N0M0 }\end{array}$ & $\begin{array}{l}\text { Bxy, Subtotal } \\
\text { gastrectomy+ } \\
\text { omentectomy } \\
+ \text { Lymph- } \\
\text { adenectomy } \\
2010\end{array}$ & $\begin{array}{l}\text { MDT: } \\
\text { Annual CT } \\
\text { TAP , OGD }\end{array}$ & Well \\
\hline 8- R.D & 41 & M & Dyspepsia & $\begin{array}{l}\text { Umbilicated } \\
\text { body/antral } \\
\text { lesion }<1 \mathrm{~cm} \text {, } \\
\text { EUS: } 1 \mathrm{~cm} \text {. }\end{array}$ & $\begin{array}{l}\text { OGD (2011), EUS (2011). CT TAP } \\
\text { (2011):Thickened greater curve } \\
\text { wall with < or }=5 \mathrm{~mm} \text { celiac } \\
\text { gastrohepatic and portahepatis } \\
\text { nodes. No mets }\end{array}$ & $\begin{array}{l}\text { WDNET, G2, } \\
\text { ki } 67: 5 \% \\
\text { T1 N0M0 }\end{array}$ & $\begin{array}{l}\text { Bxy, EMR } 2011 \\
\text { (incomplete } \\
\text { excision), Partial } \\
\text { Gasrectomy in } \\
\text { 2011, T1bN0M0 }\end{array}$ & $\begin{array}{l}\text { MDT: } \\
\text { Annual CT } \\
\text { TAP / OGD }\end{array}$ & Well \\
\hline 9- N.K & 58 & $\mathrm{~F}$ & $\begin{array}{l}\text { Dyspepsia/ } \\
\text { Pernicious } \\
\text { anaemia }\end{array}$ & $\begin{array}{l}X 2 \text { lesser curve } \\
\text { nodules }<1 \mathrm{~cm}\end{array}$ & $\begin{array}{l}\text { OGD 2005, CT TAP 2005: } \\
\text { thickened gastric wall, no discrete } \\
\text { nodule, EUS 2006. OCT } 2010 \\
\text { Normal,urine 5HIAA }\end{array}$ & $\begin{array}{l}\text { WDNET, G1, } \\
\text { ki } 67: 1 \% \\
\text { T1N0M0 }\end{array}$ & Bxy, EMR 08 & $\begin{array}{l}\text { MDT } \\
\text { Annual } \\
\text { OGD }\end{array}$ & Well \\
\hline 10-DF & 56 & M & $\begin{array}{l}\text { Pernicious } \\
\text { anaemia, } \\
\text { weight loss }\end{array}$ & $\begin{array}{l}\text { Antral polyp } \\
<0.5 \mathrm{~cm}\end{array}$ & OGD 2012, CT AP 2012: Normal & $\begin{array}{l}\text { NE } \\
\text { hyperplasia } \\
\text { CAG }\end{array}$ & Excision Bxy. & $\begin{array}{l}\text { Annual } \\
\text { OGD }\end{array}$ & Well \\
\hline 11-A. C & 44 & $\mathrm{~F}$ & Dyspepsia & Body- red spot & OGD 2014 & $\begin{array}{l}\text { NE } \\
\text { hyperplasia }\end{array}$ & Excision Bxy. & $\begin{array}{l}\text { Annual } \\
\text { OGD }\end{array}$ & Well \\
\hline
\end{tabular}

Abbreviations: OGD: Oesophagogastrodudenoscopy; Bxy: biopsy; EUS: Endoscopic mucosal resection; Oct. scan: Octreotide scan; WDNET: well differentiated neuroendocrine tumour/ Neuroendocrine carcinoma; EUS: Endoscopic ultrasound; EMR: Endoscopic mucosal resection; MDT: Multidisciplinary team meeting; PET CT: Positron emission tomography-computed tomography; CAG: Chronic active gastritis; 5-HIAA: 5- Hydroxyacetic acid; CT TAP: Computed tomography Thorax -Abdomen and Pelvis; CT AP: Computed tomography Abdomen and Pelvis; NET: Neuroendocrine tumour; NE: Neuroendocrine; WHO Grade 2010: G1,G2 and G3; KI 67: proliferation index, AJCC; TNM: Tumour, node and metastasis.

In this series, we identified a total of 11 gastric cases, that shows the wide spectrum of neuroendocrine tumours, 2 of which were neuroendocrine hyperplasia, 8 cases were well differentiated neuroendocrine tumours (WDNET) and one case of neuroendocrine carcinoma (NEC) (Table 1). Our discussion will focus on Gastric NET diagnosis and management.
In the new millennium, the World Health Organization (WHO) declared gastroenteropancreatic NET (GEP-NET) gastrointestinal carcinoids and pancreatic endocrine tumours-as the new term describing the old obsolete "carcinoid" $[5,6]$. Both the WHO and the American joint committee on cancer (AJCC) TNM and stage classifications served a better understanding in addressing them [6, 
7]. Albeit most of the NET tumours are silent some are functional. This is due to the ability of neuroendocrine cells to express synaptophysin, chromogranin A (CgA) and other humoral factors that cause carcinoid syndrome (cutaneous flushing and secretory diarrhoea) to occur in about $10 \%$ of the cases [5].

Gastric NETs specific biochemical tests include serum gastrin and CgA levels. H. Pylori antibodies, parietal cell antibodies, thyroid functional test and thyroperoxidase antibodies to better define chronic atrophic gastritis and possible association with autoimmune thyroiditis [8]. Serum chromogranin $\mathrm{A}$ is a valuable tumour marker in Gastric NETs [5, 9]. About $80 \%$ of patients have elevated levels which parallels overall tumour burden [10]. In carcinoid syndrome, a twenty-four-hour urinary 5-HIAA level is 100\% sensitive and $88 \%$ specific [11]. Serum gastrin, serotonin, histamine and substance $P$ are also measured. Diagnosis is made through histology in which immunohistochemistry for CgA and synaptophysin is of utmost importance. Both the mitotic count in $10 \mathrm{HPF}$ and the Ki67 index are mandatory in all cases. Ki67 is useful to grade patients according to WHO classification 2010: G1-G3, NET [5, $12,13]$. While routine upper endoscopy help localise/ biopsy gastric lesions, endoscopic ultrasound (EUS) is an invaluable method in their management. It can precisely assess the size of the tumour and the depth of its invasion $[14,15]$. Somatostatin receptor scintigraphy (111Indiumlabeled octreotide scan), computed tomography (CT) and magnetic resonance imaging (MRI) scans are all useful in detecting primary tumour and metastasis. Nevertheless, 111 Indium-labeled octreotide scan is far more sensitive (90\%) as compared to CT and MRI (80\%) [5], these could underestimate up to $25 \%$ of cases $[16,17]$. In patients who are on long acting octreotide drugs radiolabeled metaiodobenzylguanidine (123I-MIBG) scanning is used instead as these medications alter the somatostatin receptor scintigraphy [5].

Although Gastric NETs are classically divided into Type I, II and III, some authors add Type IV which is indistinguishable from gastric adenocarcinomas apart from exhibiting neuroendocrine cells within their matrix-debatable issue $[5,6]$. In this series, index cases 1-5 and 7-9 (Table 1) were of Type I which usually accounts for $70 \%-80 \%$ of gastric NET cases. They are small multifocal lesions (median diameter of $5 \mathrm{~mm}$ ) associated with autoimmune chronic atrophic gastritis, due to gastric achlorhydria-hypergastrinemiaenterochromaffin cell hyperplasia/ tumour mechanism [5, $6,8,18]$ They occur mostly in women and are usually nonfunctioning tumors, typically found during UGI endoscopy performed for dyspepsia or for macrocytic or iron deficiency anemia They are usually benign and well differentiated (NET G1), however, rare cases of metastatic spread and bad prognosis have been described [13]. Index case 4 (Figures 1a, 1b, 1c) small polyp on OGD with haematoxylin/ eosin and synaptophysin markers on histology respectively while index case 8 (Figure 2) shows an umbilicated lesion. Endoscopic mucosal resection is the treatment for lesions $<1 \mathrm{~cm}$ without muscularis mucosa involvement. Local surgical excision is recommended for lesions $>1 \mathrm{~cm}$ to $2 \mathrm{~cm}[5,19]$, more than 5 lesions, and recurrence at a previous site, high grade differentiation or emergency bleeding [20], involvement of muscularis mucosa [21]. Suppression of hypergastrinemia by somatostatin analogs (SSA) or surgical antrectomy are still a debated modality. SSA proved good antiproliferative properties, but their role in patients with Type 1 Gastric NETs should be considered only according to expert opinion. Being usually well differentiated and with low Ki67 (NET G1), generally have an excellent prognosis. Five year survival rates are $>95 \%$ but they have an indolent clinical course with a median recurrence-free survival of 24 months [5, 18, 22, 23]. Guidelines for post treatment surveillance from the National Comprehensive Cancer Network NCCN, the North American Neuroendocrine Tumour Society (NANETS) and the European Neuroendocrine Tumour Society (ENETS) of Type I and II gastric carcinoids $\leq 2 \mathrm{~cm}$ include history and physical examination with 6 to 12 monthly upper endoscopy for three years and annually thereafter. Imaging is reserved for clinically indicated cases [24, 25].

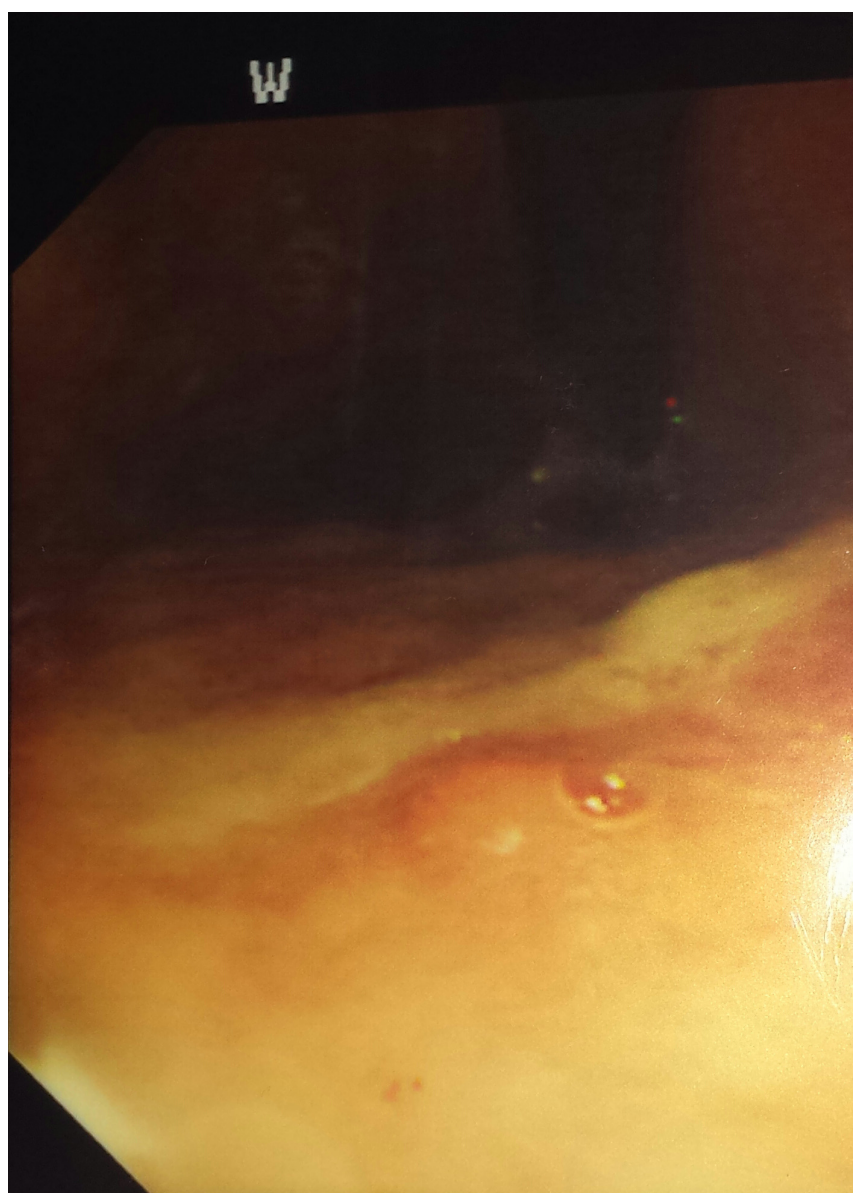

Figure 1a Type I small polyp.

There were no Type II cases in our series. This coincides with their low rate of approximately $5 \%$ of gastric NET cases. These are associated with Zollinger-Ellison syndrome, tumour driven hypergastrinemia from a pancreatic or duodenal gastrinoma. They appear as small polyps (diameter $1-2 \mathrm{~cm})[6,26,27]$. Treatment and follow up is the same as in Type I although gastrectomy together with surgical excision of underlying gastrinoma may be needed. Five year survival rates are good (70\%-90\%) but still run an indolent clinical course with a metastatic rate of $10-30 \%$, these involve more frequently the liver and abdominal lymph nodes [5]. 


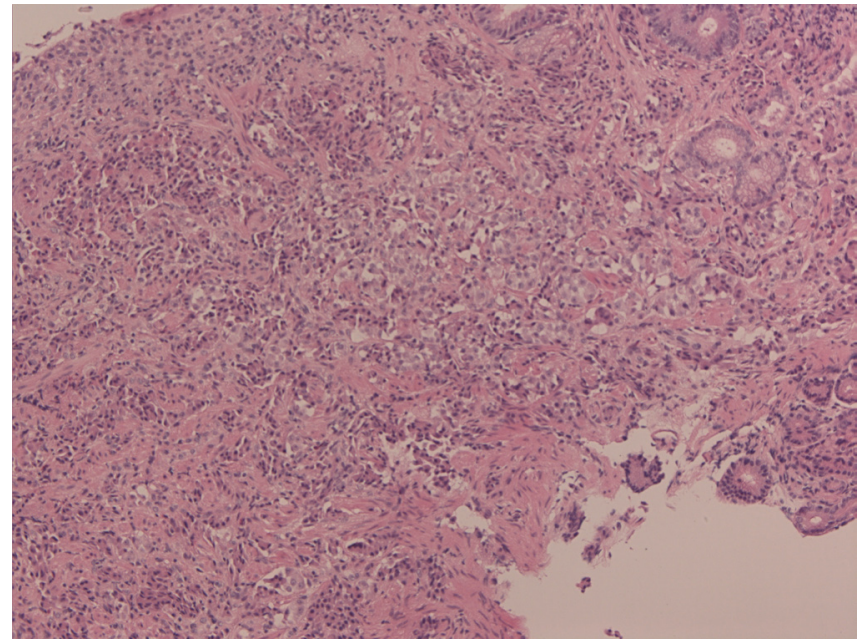

Figure $1 \mathrm{~b} \mathrm{H}$ \& E stain.

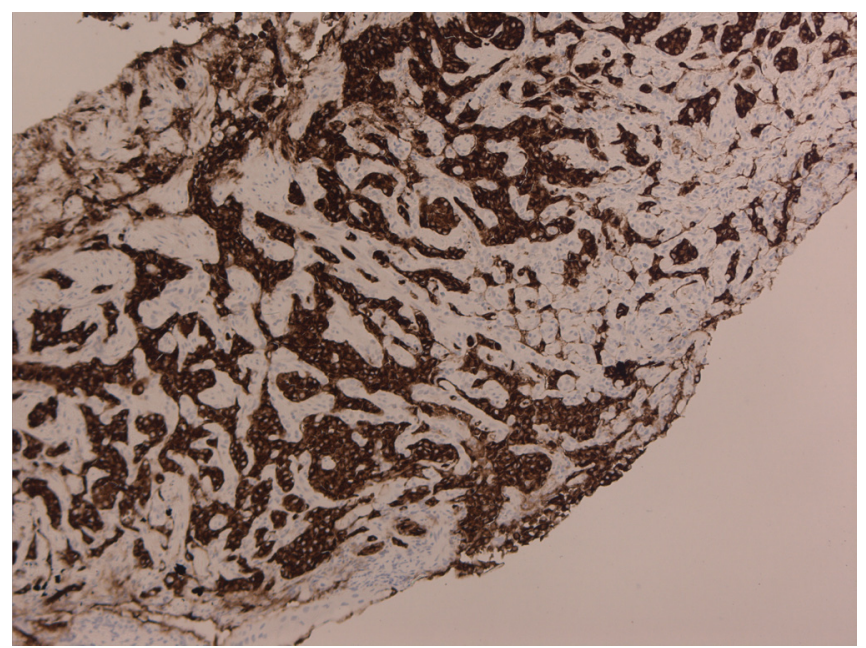

Figure 1c Synaptophysin

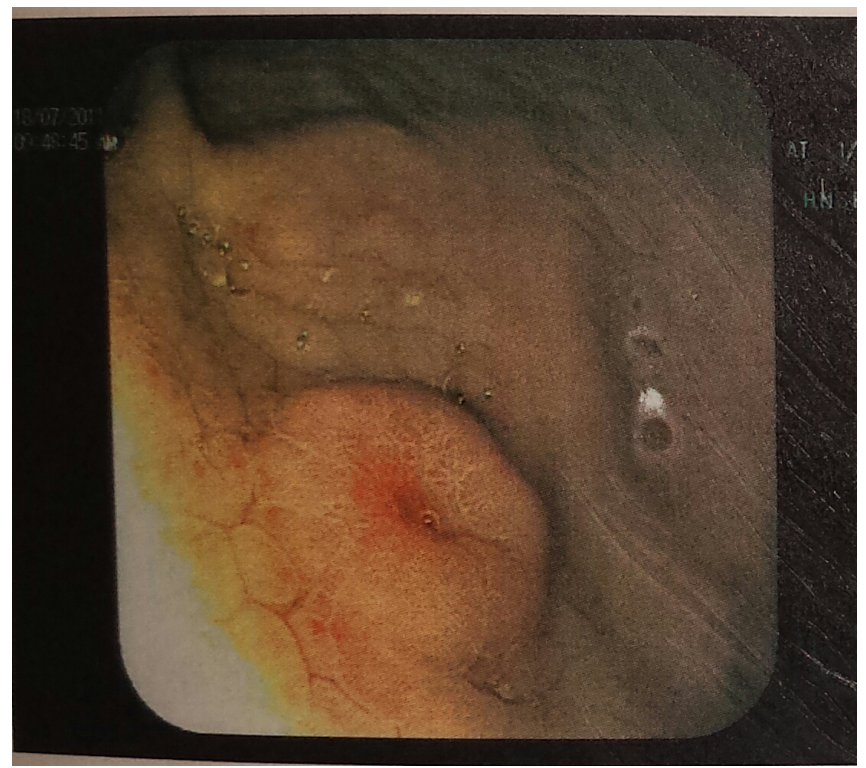

Figure 2 Type I umbilicated lesion.

One case was identified of Type III (index case 6 - Table 1, Figures $3 \mathrm{a}$ and $3 \mathrm{~b}$ with haematoxylin / eosin and synaptophysin markers on histology respectively) see link. This type represents $20 \%$ of Gastric-NETs. They are usually solitary and mostly belong to WHO group 3 (NEC G3), with high Ki67 (>20), big diameter with infiltrative growth; they occur mostly in men over 50 years of age [23]. They are sporadic aggressive lesions with metastatic potential. Treatment is by total or partial gastrectomy with lymph node dissection as gastric adenocarcinoma [28-30]. Fiveyear survival rates are $<35 \%$. Follow up should include radiological investigations (CT scan/ MRI) and CgA as per gastric adenocarcinoma protocols [5].

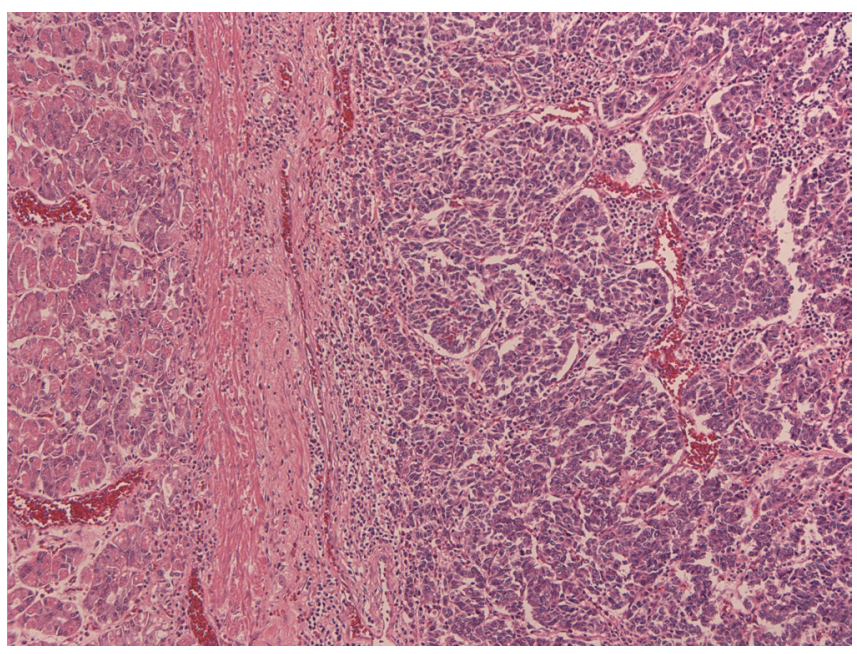

Figure 3a FB 49141 H \& E stain.

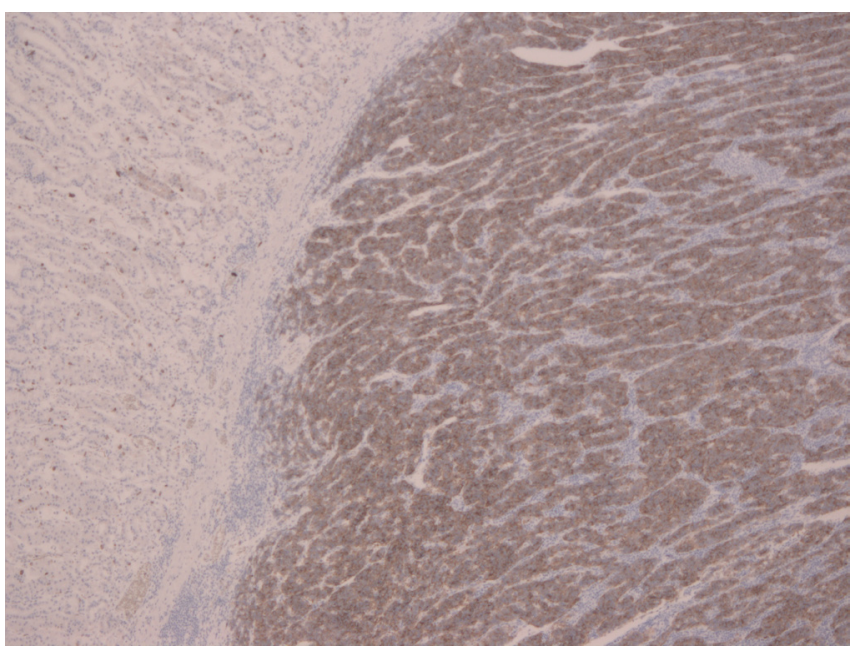

Figure 3b FB 4914 Synaptophysin.

Type IV is managed in the same way and follow up is as gastric carcinoma [5, 6]. Tumours less than $2 \mathrm{~cm}$ metastasise in less than $10 \%$ of cases [19], tumour related death and malignant transformation are also rare [31].

There were 2 cases of gastric hyperplasia identified and managed with excision biopsy and follow up annually, (Index cases 10 and 11, Table 1, case 11; Figures 4a and $4 \mathrm{~b}$ with haematoxylin/ eosin and synaptophysin markers respectively on histology). Of note other cases had some NE hyperplasia changes but not mentioned as they are upgraded to NETs.

Medical therapy has a role to play in Gastric NETs. It is used in management of functioning tumours (to control symptoms), non-functioning tumours (growth inhibition), metastatic progression and in residual disease. Either alone or in combination, somatostatin (SST) analogue 


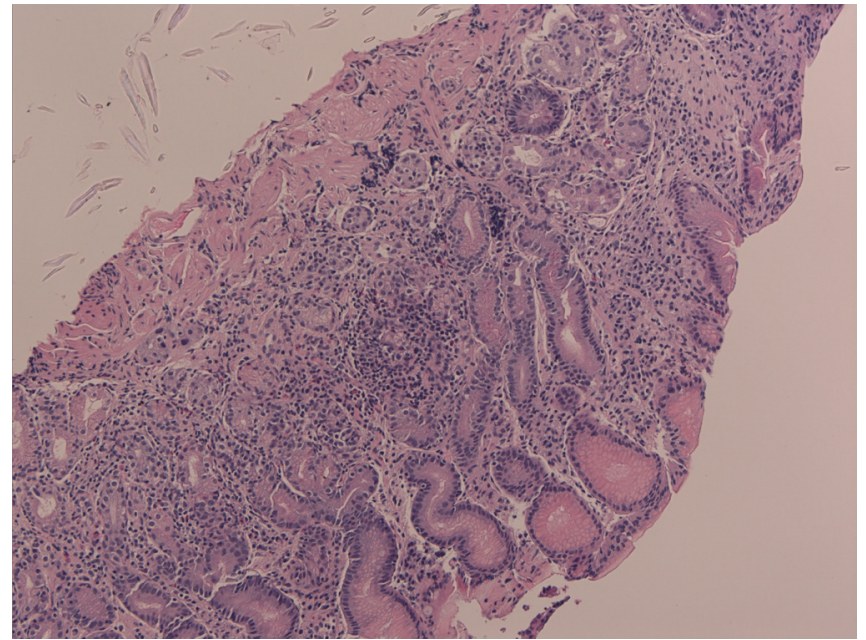

Figure 4a Hyperplasia 69081 H \& E stain.

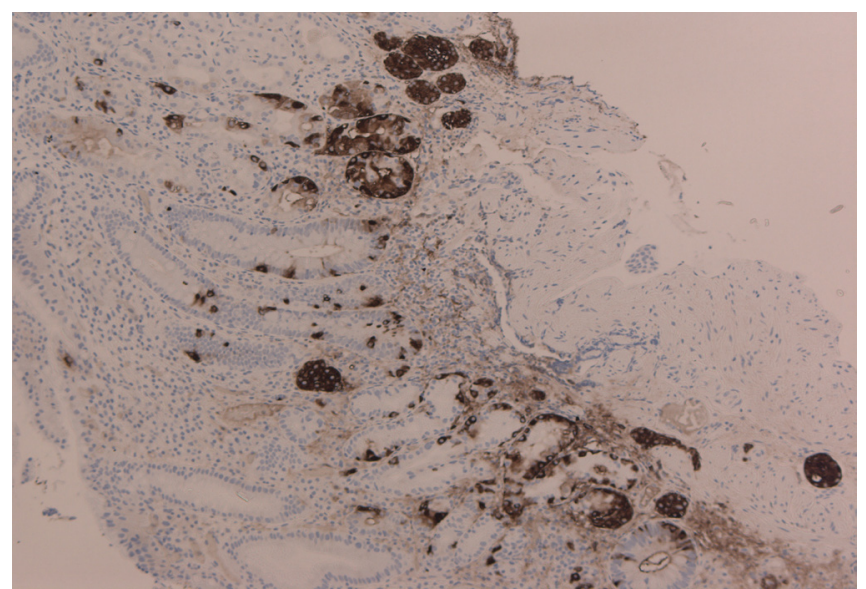

Figure 4b Hyperplasia 6908 Synaptophysin.

(short/ long acting octreotide) and interferon-a are used. In metastatic disease, systemic chemotherapy or radioisotope therapy e.g.: I-131 MIBG is also an option. For isolated liver metastasis, chaemoembolisation and radiofrequency ablation are considered [5, 32-34]. The response to medical therapy should be followed clinically and biochemically every 3 months and radiolgically 6 months for 5 years [35]. Gastric neuroendocrine cases, should be discussed individually to tailor the best management in specialised neuroendocrine tumour multidisciplinary meetings [2].

\section{Conclusion}

Although Gastric NETs are relatively rare, their incidence is increasing as part of GEP-NET rise. Gastric NETs vary through a wide clinical spectrum, from asymptomatic cases to functioning tumours. Gastrointestinal physicians and surgeons need to be aware and purse these lesions as they are indolent with a malignant variant and a potential for metastasis.

\section{Acknowledgements}

The authors would like to thank the staff in the pathology and medical records departments for their help in retrieving and collecting data.

\section{Conflict of interest}

The authors declare no conflict of interest.

\section{References}

[1] Kulke MH, Mayer RJ. Carcinoid tumors. N Engl J Med. 1999; 340(11):858-868.

[2] Basuroy R, Srirajaskanthan R, Prachalias A, Quaglia A, Ramage JK. Review article: the investigation and management of gastric neuroendocrine tumours. Aliment Pharmacol Ther. 2014; 39(10):1071-1084.

[3] Taghavi S, Jayarajan SN, Powers BD, Davey A, Willis Al. Examining rectal carcinoids in the era of screening colonoscopy: a surveillance, epidemiology, and end results analysis. Dis Colon Rectum. 2013; 56(8):952-959.

[4] Niederle MB, Hackl M, Kaserer K, Niederle B. Gastroenteropancreatic neuroendocrine tumours: the current incidence and staging based on the WHO and European Neuroendocrine Tumour Society classification: an analysis based on prospectively collected parameters. Endocr Relat Cancer. 2010; 17(4):909-918.

[5] Modlin IM, Kidd M, Latich I, Zikusoka MN, Shapiro MD. Current status of gastrointestinal carcinoids. Gastroenterology 2005; 128(6):17171751.

[6] Klöppel G, Perren A, Heitz PU. The gastroenteropancreatic neuroendocrine cell system and its tumors: the WHO classification. Ann N Y Acad Sci. 2004; 1014:13-27.

[7] Rindi G, Klöppel G, Couvelard A, Komminoth P, Körner M, et al. TNM staging of midgut and hindgut (neuro) endocrine tumors: a consensus proposal including a grading system. Virchows Arch. 2007; 451(4):757-762.

[8] Merola E, Sbrozzi-Vanni A, Panzuto F, D'Ambra G, Di Giulio E, et al. Type I gastric carcinoids: a prospective study on endoscopic management and recurrence rate. Neuroendocrinology. 2012; 95(3):207-213.

[9] Ghevariya V, Malieckal A, Ghevariya N, Mazumder M, Anand S. Carcinoid tumors of the gastrointestinal tract. South Med J. 2009; 102(10):1032-1040.

[10] Stivanello M, Berruti A, Torta M, Termine A, Tampellini M, et al. Circulating chromogranin $A$ in the assessment of patients with neuroendocrine tumours. A single institution experience. Ann Oncol. 2001; 12(Suppl 2): S73-S77.

[11] Tormey WP, FitzGerald RJ. The clinical and laboratory correlates of an increased urinary 5-hydroxyindoleacetic acid. Postgrad Med J. 1995: 71(839):542-545.

[12] Rindi G, Luinetti O, Cornaggia M, Capella C, Solcia E. Three subtypes of gastric argyrophil carcinoid and the gastric neuroendocrine carcinoma: a clinicopathologic study. Gastroenterology. 1993; 104(4):994-1006.

[13] Rindi G, Arnold R, Bosman FT. Nomenclature and classification of neuroendocrine neoplasms of the digestive system. In: Bosman FT, Carneiro F, Hruban RH, Theise ND, et al., editors. WHO classification of tumors of the digestive system. Lyon: IARC; 2010; pp13-14.

[14] Ichikawa J, Tanabe S, Koizumi W, Kida Y, Imaizumi H, et al. Endoscopic mucosal resection in the management of gastric carcinoid tumors. Endoscopy. 2003; 35(3):203-206.

[15] Ishii N, Horiki N, Itoh T, Maruyama M, Matsuda M, et al. Endoscopic submucosal dissection and preoperative assessment with endoscopic ultrasonography for the treatment of rectal carcinoid tumors. Surg Endosc. 2010; 24(6):1413-1419.

[16] Pasieka JL. Carcinoid tumors. Surg Clin North Am. 2009; 89(5):11231137.

[17] Orlefors H, Sundin A, Garske U, Juhlin C, Oberg K, et al. Whole-body (11)C-5- hydroxytryptophan positron emission tomography as a universal imaging technique for neuroendocrine tumors: comparison with somatostatin receptor scintigraphy and computed tomography. J Clin Endocrinol Metab. 2005; 90(6):3392-3400.

[18] Thomas D, Tsolakis AV, Grozinsky-Glasberg S, Fraenkel M, Alexandraki $\mathrm{K}$, et al. Long-term follow-up of a large series of patients with type 1 gastric carcinoid tumors: data from a multicenter study. Eur J Endocrinol. 2013; 168 (2):185-193.

[19] Soga J. Early-stage carcinoids of the gastrointestinal tract: an analysis of 1914 reported cases. Cancer. 2005; 103(8):1587-1595.

[20] Jordan PH Jr, Barroso A, Sweeney J. Gastric carcinoids in patients with hypergastrinemia. J Am Coll Surg. 2004; 199(4):552-555.

[21] Gladdy RA, Strong VE, Coit D, Allen PJ, Gerdes H, et al. Defining surgical indications for type I gastric carcinoid tumor. Ann Surg Oncol. 2009; 16(11):3154-3160.

[22] Grozinsky-Glasberg S, Kaltsas G, Gur C, Gal E, Thomas D, et al. Longacting somatostatin analogues are an effective treatment for type 1 gastric carcinoid tumours. Eur J Endocrinol. 2008; 159(4):475-482. 
[23] Bordi C. Gastric carcinoids. Ital J Gastroenterol Hepatol 1999; 31(suppl 2):S94-S97.

[24] BoudreauxJP, Klimstra DS, Hassan MM, Woltering EA, Jensen RT, et al. The NANETS consensus guideline for the diagnosis and management of neuroendocrine tumors: well-differentiated neuroendocrine tumors of the Jejunum, lleum, Appendix, and Cecum. Pancreas. 2010; 39(6):753-766.

[25] Arnold R, Chen Y], Costa F, Falconi M, Gross D, et al. ENETS Consensus Guidelines for the Standards of Care in Neuroendocrine Tumors: follow-up and documentation. Neuroendocrinology. 2009; 90(2):227233.

[26] Delle Fave G, Capurso G, Milione M, Panzuto F. Endocrine tumours of the stomach. Best Pract Res Clin Gastroenterol. 2005; 19(5):659673.

[27] Von Rosenvinge EC, Wank SA, Lim RM. Gastric masses in multiple endocrine neoplasia type I-associated Zollinger-Ellison syndrome. Gastroenterology. 2009; 137(4):1222-537.

[28] Gilligan Cl, Lawton GP, Tang LH, West AB, Modlin IM. Gastric carcinoid tumors: the biology and therapy of an enigmatic and controversial lesion. Am J Gastroenterol. 1995; 90(3):338-352.

[29] Plöckinger U, Rindi G, Arnold R, Eriksson B, Krenning EP, et al. Guidelines for the diagnosis and treatment of neuroendocrine gastrointestinal tumours. A consensus statement on behalf of the European Neuroendocrine Tumour Society (ENETS). Neuroendocrinology. 2004; 80(6):394-424.

[30] Delle Fave G, Kwekkeboom DJ, Van Cutsem E, Rindi G, Kos-Kudla B, et al. ENETS Consensus Guidelines for the management of patients with gastroduodenal neoplasms. Neuroendocrinology. 2012; 95(2):7487.

[31] SchindI M, Kaserer K, Niederle B. Treatment of gastric neuroendocrine tumors: the necessity of a type-adapted treatment. Arch Surg. 2001; 136(1):49-54.

[32] Ramage JK, Davies AH, Ardill J, Bax N, Caplin M, et al. Guidelines for the management of gastroenteropancreatic neuroendocrine (including carcinoid) tumours. Gut. 2005; 54 Suppl 4:iv1-iv16.

[33] Oberg K, Astrup L, Eriksson B, Falkmer SE, Falkmer UG, et al. Guidelines for the management of gastroenteropancreatic neuroendocrine tumours (including bronchopulmonary and thymic neoplasms). Part I-general overview. Acta Oncol 2004; 43(7):617-625.

[34] Srirajaskanthan R, Toumpanakis C, Meyer T, Caplin ME. Review article: future therapies for management of metastatic gastroenteropancreatic neuroendocrine tumours. Aliment Pharmacol Ther. 2009; 29(11):1143-1154.

[35] Oberg K, Jelic S, ESMO Guidelines Working Group. Neuroendocrine gastroenteropancreatic tumors: ESMO clinical recommendation for diagnosis, treatment and follow-up. Ann Oncol. 2009; 20 Suppl 4:150-153. 